\title{
Evaluation of forestripping milk and its effects on milk quality
}

\author{
Avaliação do leite do teste de Tamis e seu efeito sobre a qualidade do leite

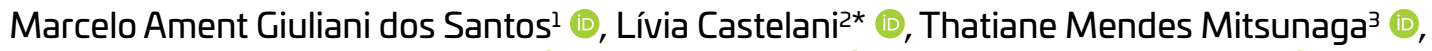 \\ Weber Vilas Boas Soares ${ }^{2} \odot$, Rodrigo Giglioti ${ }^{4}$, Luiz Carlos Roma Júnior ${ }^{2}$ ()
}

\begin{abstract}
Consumers demand for food safety affects dairy industry, restraining the sector to adapt to milk quality parameters established by legislation, such as somatic cell count (SCC) and standard plate count (SPC). Good agricultural practices have positive impact over these parameters, especially Forestripping Milk (FSM), which consists of observing the first milk streams collected in a dark-bottomed mug for identification of clinical mastitis. These first milk streams have high somatic cells count and bacteria. Therefore, the aim of this study was to evaluate the characteristics of milk from FSM, such as SCC and SPC values, and its impacts on milk quality of the cooling tank through simulating contamination. Fourteen dairy farms and one experimental farm were evaluated for SCC and SPC parameters of FSM. It was observed that there was no statistically significant difference for SCC and SPC between milk samples from the cooling tank and cooling tank simulating the inclusion of milk from FSM. Statistically significant difference for somatic cell score (SCS) and SPC was observed when tanks were classified by SCC. In addition, difference in SCS was observed between morning and afternoon milking. The collection of first milk streams can contribute to decrease in SCC and SPC of milk in the cooling tank. FSM must be practiced by all dairy farmers as milking management, to assist in clinical mastitis diagnosis and improve milk quality.
\end{abstract}

KEYWORDS: Good agricultural practices; Somatic Cell Count; Standard Plate Count; bovine milk; quality payment.

RESUMO: A exigência dos consumidores por alimentos seguros pressiona a indústria leiteira a se adequar aos parâmetros estabelecidos pela legislação, como a contagem de células somáticas (CCS) e a contagem padrão em placas (CPP). As boas práticas agropecuárias impactam positivamente sobre esses parâmetros, destacando-se o teste de Tamis ou Forestripping Milk (FSM), que consiste na observação dos primeiros jatos de leite retirados em uma caneca de fundo escuro para a identificação da mastite clínica. Esses primeiros jatos possuem elevada quantidade de células somáticas e bactérias. O objetivo deste estudo foi avaliar as características do leite do FSM quanto aos valores de CCS e CPP, e seus impactos na qualidade do leite do tanque de resfriamento por meio de simulação de contaminação. Foram avaliadas 14 propriedades leiteiras comerciais e uma experimental quanto aos parâmetros de CCS e CPP oriundos do FSM. Observou-se que não houve diferença significante para CCS e CPP entre as amostras de leite do tanque e do tanque simulando a inclusão de leite do FSM. Diferenças estatisticamente significativas para escore de CCS e CPP foram observadas quando os tanques foram classificados por CCS. Além disso, foi observada diferença nas CCS entre as ordenha da manhã e da tarde. A coleta dos primeiros fluxos de leite pode contribuir na redução da CCS e da CPP do leite do tanque de resfriamento. O FSM deve ser praticado por todos os produtores de leite no manejo da ordenha para auxiliar no diagnóstico clínico da mastite e melhorar a qualidade do leite.

PALAVRAS-CHAVE: boas práticas agropecuárias; Contagem de Células Somáticas; Contagem Padrão em Placa; leite bovino; pagamento por qualidade.

\section{INTRODUCTION}

Milk is considered a nutritionally complete food capable of acting on the body providing growth and regulating nervous and immune systems. The increasingly demanding consumer requires improvement of the production system to provide safer and improved quality food (MELO SOARES et al., 2019).

Normative Instruction (NI) No. 76, published in 2018 by the Ministry of Agriculture, Livestock and Supply of Brazil (MAPA), establishes that milk quality must be determined by

${ }^{1}$ Coordenadoria de Desenvolvimento Rural Sustentável, CDRS/CATI, Itapetininga, Brazil. 2Centro de Pesquisa de Bovinos de Leite, Instituto de Zootecnia, Nova Odessa, SP, Brazil. 'Departamento de Zootecnia, ESALQ, Universidade de São Paulo, Piracicaba, Brazil.

${ }^{4}$ Centro de Genética e Reprodução Animal, Instituto de Zootecnia, Nova Odessa, SP, Brazil.

*Corresponding author: liviacastelani@gmail.com

Received: 31/03/2021. Accepted: 03/09/2021 
physicochemical parameters (alizarol stability, titratable acidity, relative density, cryoscopic index), composition (fat, protein, defatted dry extract) and hygienic-sanitary standards, such as standard plate count (SPC), somatic cell count (SCC) and detection of antibiotic residues (BRAZIL, 2018). Milk composition quality is mainly influenced by diet, management and breed, among others (SANTOS; FONSECA, 2019). Hygienic-sanitary standards are mainly related to the health of animals, especially mastitis, milking management and milk storage conditions (DIAS; ANTES, 2014).

The use of good agricultural practices (GAP) has positive impact on these parameters and should be carried out from the beginning of milking until milk processing. Among these good practices, Forestripping Milk (FSM) or dark-bottomed mug test stands out. This test is used for the diagnosis of clinical mastitis and consists of observing the first milk streams collected in a dark-bottomed screened mug to evaluation of visible abnormalities in milk, such as presence of lumps. In addition, it can assist in decreasing bacterial count and somatic cells, which are naturally present in the first milk streams (SANTOS; FONSECA, 2019).

Milk quality from cooling tank is influenced by different factors. One of these factors is milking management, in which the FSM is performed as an important test for monitoring clinical mastitis in the herd. However, there is no evidence of this daily practice' impacts on milk quality from cooling tank. Therefore, the aim of this study was to evaluate the characteristics of milk from FSM, such as SCC and SPC values, and its impacts on milk quality of the cooling tank through simulating contamination.

\section{MATERIAL AND METHODS}

\section{Ethics Committee}

There was no manipulation of animals by the research team in this research project. Samples were collected by dairy farmers themselves.

\section{The experiment was conducted in two stages}

Stage 1: The impact of FSM on hygienic-sanitary aspects (SCC and SPC) of milk samples from cooling tanks was evaluated. Fourteen dairy farms from local dairy cooperative society, located in the in the region of Piracicaba, state of São Paulo, Brazil, were evaluated. Properties had on average 21 hectares, 32 crossbred Holstein x Gyr lactating cows and average milk production of $246 \mathrm{~L} /$ day, collected by the cooperative. Farmers performed two daily milkings (05:00 am and 02:00 pm), and the presence of calf near the cow was observed in 11 farms. Ten farms used bucket-type milking, two used milking pipeline system and two performed manual milking. Only five farmers performed pre-dipping, 12 dried udders before milking and only three performed post-dipping. All farmers had milk cooling tank.

Considering milking facilities, only two properties had holding area before milking parlour. Stage 2: SCC and SPC characteristics of milk from FSM were analyzed according to morning and afternoon milkings. This stage was developed at the experimental farm of the Milk Bovine Research Center, Animal Science Institute, located in Americana, São Paulo, Brazil. The farm had on average 95 Holstein lactating cows, with average milk production of $1,900 \mathrm{~L} /$ day. Cows were milked at 07:00 am and 03:00 pm. Milking was mechanized in line with pit, with udder washing when necessary, followed by mandatory pre-dipping, drying and post-dipping. The experimental farm also had milk cooling tank.

Sampling: Samples were collected between October 2017 and January 2018. Stage 1 consisted of collection of milk from the cooling tank and FSM from all lactating cows in each farm, carried out only in the morning milking. Collections of milk from FSM were carried out by milkers shortly after the milking management process before the placement of liners and before calf suckling (in properties with calf at foot). All milk from FSM was transferred to previously cleaned and sanitized buckets to measure the total collected volume, as well as homogenization for sampling. At the end of milking, the volume of milk produced was directly measured in the cooling tank, followed by sampling of previously homogenized milk. Forty $\mathrm{mL}$ aliquots, both for sampling of milk from FSM and for sampling of milk from the cooling tank, were added in flasks containing Bronopol ${ }^{\oplus}$ and Azidiol ${ }^{\oplus}$ to determine SCC and SPC, respectively, kept under refrigeration for up to three days and sent to the "Clínica do Leite" Laboratory (ESALQ / USP). SCC and SPC were performed by flow cytometry using Fossomatic FC (FOSS A/S Hillerod, Denmark) and BactoScan FC (FOSS A/S Hillerod, Denmark) apparatuses, respectively.

For Stage 2, for 18 consecutive days, milk from FSM in the morning and afternoon milkings was sampled. Collection procedure and SPC and SCC analyses were performed as described in Stage 1.

\section{Statistical analysis}

To understand the effect of FSM on the milk tank in Stage 1 , a calculation was performed simulating the proportional presence of FSM in the total milk volume of cooling tank. For Stage 1, average SCC and SPC values of cooling tank samples were used in relation to averages calculated, just for morning milking. For Stage 2, averages of volume, SCC, SPC from FSM in the morning milking were compared to the afternoon milking.

For approximation of normal data distribution, SCC values were converted into somatic cell scores (SCS) (ALI;SHOOK, 1980) according to the equation below: 
$\mathrm{SCS}=\log _{2}(\mathrm{SCC} / 100)+3$

SPC data were transformed by the base 10 logarithmic function. SCS and SPC log results were analyzed using generalized linear models using the GLM procedure of the SAS 9.3 statistical package. The comparison of averages with and without FSM and comparison between milking times (morning and afternoon) were analyzed using the Student's t-test $(P<0.05)$.

For data analysis, cooling tanks were classified into tanks with high SCC and low SCC, with $500 \times 10^{3}$ cells $/ \mathrm{mL}$ being the separation value of groups according to Normative Instruction 76 (BRAZIL, 2018). Likewise, tanks were separated according to SPC values, with $300 \times 10^{3} \mathrm{CFU} / \mathrm{mL}$ being the separation value of groups.

Table l. Somatic Cell Count (SCC) and Standard Plate Count (SPC) of milk samples from the cooling tank before and after simulating the inclusion of milk from FSM.

\begin{tabular}{l|c|c|c|c} 
& Before & After & SEM & $P$-value \\
$\begin{array}{l}\text { Somatic Cell Count } \\
\left(\times 10^{3} \text { cells/mL) }\right.\end{array}$ & 409 & 414 & - & - \\
\hline Somatic Cell Score & 5.03 & 5.05 & 0.76 & 0.88 \\
\hline $\begin{array}{l}\text { Standard Plate Count } \\
\left(\times 10^{3} \text { CFU/mL) }\right.\end{array}$ & 61 & 76 & - & - \\
\hline SPC log & 1.78 & 1.88 & 0.50 & 0.65 \\
\hline
\end{tabular}

SEM - Standard Error of the Means. $P$ : significant value at $\leq 0.05$ in the Student's T test.

\section{RESULTS}

In Stage 1, it was observed that there was no statistically significant difference for SCC and SPC between milk samples from the cooling tank and the cooling tank simulating the inclusion of milk from FMS (Table 1). The average volume of milk from FSM was $910 \mathrm{~mL}$, with average SCC of $1.067 \times 10^{3}$ cells $/ \mathrm{mL}$ and average SPC of $2.415 \times 10^{3} \mathrm{CFU} / \mathrm{mL}$.

From the classifications of farms by values of parameters determined by NI 76, statistically significant differences were observed $(P=0.04)$, considering the SCS of tanks with high SCC. Statistically significant difference for SPC $\log (P<0.01)$ and SCS $(P=0.01)$ was observed in the classification of tanks by SPC values (Table 2 ).

Regarding aspects of milk from FSM, statistically significant difference was observed for SCS $(P=0.01)$ and for SPC $(P<0.01)$, when tanks were classified by SCC (Table 3$)$.

Results of Stage 2 are described in Table 4. Statistically significant variations were observed in the volume of milk from FSM, total and per udder, and SCS as a function of the milking period. The highest amounts of total milk volume and per udder were observed in the morning milking. Regarding SCS, values were higher in the afternoon milking.

\section{DISCUSSION}

FSM did not show significant effect on the SCC and SPC of milk from cooling tanks, when the average values of all farms evaluated were analyzed (Table 1). It could then be inferred that these results are related to the dilution of milk obtained from FSM, from the moment it was mixed with the volume of

Table 2. Averages of hygienic-sanitary parameters of milk from cooling tanks classified according to Somatic Cell Count (SCC) and Standard Plate Count (SPC) before and after simulating the inclusion of milk from FSM.

\begin{tabular}{|c|c|c|c|c|c|}
\hline \multicolumn{2}{|l|}{ Tank Classification } & Before & After & SEM & $P$-value \\
\hline \multirow{4}{*}{$\begin{array}{l}\text { Low SCC } \\
\left(<500 \times 10^{3} \text { cells } / \mathrm{mL}\right)\end{array}$} & SCC $x 10^{3}$ cell $/ \mathrm{mL}$ & 336 & 353 & - & - \\
\hline & Somatic cell score & $4.75^{a}$ & $4.82^{\mathrm{a}}$ & 0.76 & 0.65 \\
\hline & $\mathrm{SPC} \times 10^{3} \mathrm{CFU} / \mathrm{mL}$ & 79 & 81 & - & - \\
\hline & SPC log & $1.90^{a}$ & $1.91^{\mathrm{a}}$ & 0.50 & 0.96 \\
\hline \multirow{4}{*}{$\begin{array}{l}\text { High SCC } \\
\left.\text { (> } 500 \times 10^{3} \text { cells } / \mathrm{mL}\right)\end{array}$} & $\mathrm{SCC} \times 10^{3}$ cells $/ \mathrm{mL}$ & 354 & 551 & - & - \\
\hline & Somatic cell score & $4.82^{\mathrm{a}}$ & $5.46^{b}$ & 0.76 & 0.04 \\
\hline & $\mathrm{SPC} \times 10^{3} \mathrm{CFU} / \mathrm{mL}$ & 80 & 188 & - & - \\
\hline & SPC log & 1.90 & 2.28 & 0.55 & 0.30 \\
\hline \multirow{4}{*}{$\begin{array}{l}\text { Low SPC } \\
\left(<300 \times 10^{3} \text { cells } / \mathrm{mL}\right)\end{array}$} & SCC $\times 10^{3}$ cells $/ \mathrm{mL}$ & 354 & 403 & - & - \\
\hline & Somatic cell score & $4.83^{\mathrm{a}}$ & $5.01^{\mathrm{a}}$ & 0.76 & 0.24 \\
\hline & $\mathrm{SPC} \times 10^{3} \mathrm{CFU} / \mathrm{mL}$ & 50 & 80 & - & - \\
\hline & SPC log & $1.70^{a}$ & $1.90^{\mathrm{a}}$ & 0.55 & 0.28 \\
\hline \multirow{4}{*}{$\begin{array}{l}\text { High SPC } \\
\text { (> } 300 \times 10^{3} \text { cells } / \mathrm{mL} \text { ) }\end{array}$} & SCC $\times 10^{3}$ cells $/ \mathrm{mL}$ & 320 & 348 & - & - \\
\hline & Somatic cell score & 4.68 & 4.80 & 0.76 & 0.01 \\
\hline & $\mathrm{SPC} \times 10^{3} \mathrm{CFU} / \mathrm{mL}$ & 81 & 512 & - & - \\
\hline & SPC log & $1.91^{\mathrm{a}}$ & $2.71^{\mathrm{b}}$ & 0.55 & 0.0059 \\
\hline
\end{tabular}

SEM - Standard Error of the Means. $P$ : significant value at $\leq 0.05$ in the Student's T test. a,b: In each row, means followed by different statistically significant difference $(P \leq 0.05)$. 
Table 3. Somatic Cell Count (SCC) and Standard Plate Count (SPC) of milk samples from FSM, grouped into High SCC, Low SCC and High SPC, Low SPC.

\begin{tabular}{|c|c|c|c|c|c|}
\hline \multicolumn{6}{|c|}{ Analysis of FSM in relation to SCC } \\
\hline & $\operatorname{SCC}<500$ & SEM & $S C C>500$ & SEM & $P$-value \\
\hline SCC $x 10^{3}$ cells $/ m L$ & 875 & - & 2210 & - & - \\
\hline Somatic cell score & $6.1288^{a}$ & 1.3787 & $7.4657^{b}$ & 0.5352 & 0.0187 \\
\hline $\mathrm{SPC} \times 10^{3} \mathrm{UFC} / \mathrm{mL}$ & 940 & - & 983 & - & - \\
\hline SPC log & 2.9733 & 0.5419 & 2.9925 & 0.3066 & 0.9441 \\
\hline \multicolumn{6}{|c|}{ Analysis of FSM in relation to SPC } \\
\hline & $\mathrm{SPC}<300$ & SEM & $\mathrm{SPC}>\mathbf{3 0 0}$ & SEM & $P$-value \\
\hline SCC $x 10^{3}$ cells $/ \mathrm{mL}$ & 1188 & - & 988 & - & - \\
\hline Somatic cell score & 6.5707 & 1.3503 & 6.305 & 1.4029 & 0.3206 \\
\hline $\mathrm{SPC} \times 10^{3} \mathrm{UFC} / \mathrm{mL}$ & 730 & - & 1977 & - & - \\
\hline SPC log & 2.8635 & 0.5198 & 3.296 & 0.2198 & 0.0933 \\
\hline
\end{tabular}

SEM - Standard Error of the Means. $P$ : significant value at $\leq 0.05$ in the Student's $T$ test. ${ }^{a, b}$ : In each row, means followed by different statistically significant difference $(P \leq 0.05)$.

Table 4. Aspects of milk from FSM as a function of morning and afternoon milking.

\begin{tabular}{l|c|c|c|c|c} 
& Morning & SEM & Afternoon & SEM & P-value \\
\hline Total volume of milk from FSM $(\mathrm{mL})$ & 1710 & 0.6952 & 1190 & 0.7197 & 0.0451 \\
\hline Volume of milk from FSM per udder $(\mathrm{mL})$ & 4.88 & 1.6291 & 3.32 & 1.6493 & 0.0104 \\
\hline Somatic Cell Count $\left(\mathrm{x} 10^{3}\right.$ cell/mL) & 2361 & - & 18746 & - & - \\
\hline Somatic Cell Score & 7.31 & 0.876 & 10.35 & 0.849 & $<0.0001$ \\
\hline Standard Plate Count $\left(\times 10^{3} \mathrm{CFU}\right)$ & 344 & - & 143 & - & - \\
\hline SPC log & 2.29 & 0.4834 & 2.08 & 0.2652 & 0.2355 \\
\hline
\end{tabular}

SEM - Standard Error of the Means. P: significant value at $\leq 0.05$ in the Student's T test.

milk from the cooling tank. This dilution represented $0.36 \%$ of the total tank volume.

Although no effect was observed in this study, it is important to highlight the relevance of implementing FSM. It is a procedure that is easy to perform, has low cost and recognized importance for the detection of clinical mastitis, helping to reduce the SCC of the tank milk. Furthermore, the collection of the first milk streams eliminates microorganisms belonging to the udder microbiota, consequently reducing SPC (RUEGG, 2003; WAGNER; RUEGG, 2002). In addition, FSM as a premilking routine has beneficial effects on the physiological mechanisms of milk ejection reflex, by tactile stimulation of human hand during milk stripping (WATTERS et al., 2015; WAGNER; RUEGG, 2002). In crossbred Gyr cows, where maternal bond with calf is strong and milk ejection depend on calf presence, tactile stimuli showed higher oxytocin concentrations that are important in milk letdown (UJITA et al., 2021). However, there are other factors that may influence milk ejection effectiveness, such as stage of lactation, age and breed (WATTERS et al., 2015).

The implementation of FSM and its relationship with the hygienic-sanitary parameters of milk was also the aim of other authors. A study characterized 71 American farms that were within SCC parameters established by the Dairy Herd
Improvement Association (DHIA), and the milking management was pointed out by farmers as essential to keep SCC values below the established limit. In addition, the management most cited by farmers (15\%) was FSM (STERRET;BEWLEY, 2013). Regarding hygiene aspects, Bava et al. (2011) evaluated 22 farms in northern Italy with the aim of identifying aspects of good milking practices and their relationship with SPC. The authors identified that the implementation of FSM was related to SPC, and of farms with milk from tanks with high SPC, only $35 \%$ of them performed FSM, as opposed to those with milk from tanks with low SPC, in which all performed this procedure.

In a study conducted by Yamazi et al. (2010), bacterial contamination of milk was compared before and after the performance of FSM, where the authors found reductions of $77.5 \%$ in mesophilic aerobic bacteria, $97.9 \%$ in psychrotrophic bacteria, $43.1 \%$ in total coliforms and $52.8 \%$ in Escherichia coli. The microbial contamination of raw milk is affected by different factors, such as presence of mastitis, milking hygiene and implementation of good practices, water quality, and milk storage time and temperature after milking (MENEZES et al., 2014).

Conversely, when cutoff values are applied according to NI 76 criteria, it is observed that the implementation of 
FSM would significantly affect the SCC values of milk from tank with values above established ones. In addition, it was observed that producers with tank milk SCC values below those established by legislation would not be affected by contamination of milk from FSM (Table 2). These results may be related to differences in milking management, good practices and mastitis control adopted by evaluated dairy farms. Reyes et al. (2017) evaluated 130 dairy farms in the northeastern region of Antioquia, Colombia, over 24 months, and demonstrated that $38 \%$ of producers did not perform FSM, which contributed to the $27 \%$ increase in SCC in the tank milk of these producers.

It is important to highlight that the quality of Brazilian milk is much lower than standards established by legislation. In 2015, of the total of 44 thousand herds that sent milk samples to the "Clínica do Leite" laboratory / ESALQ / USP, 28\% and $35 \%$ had SCC and SPC values, respectively, above limits established by NI 62, the current legislation at the time (CASSOLI; MACHADO, 2016a; CASSOLI; MACHADO, 2016b).

Brazilian dairy production is heterogeneous, with properties using advanced technologies, as well as those using rudimentary techniques. Many producers still perform ineffective milking and management practices, producing low quality product with low market value, resulting in economic losses to the industry (WERNCKE et al., 2016). The lack of knowledge makes many producers believe that obtaining higher quality milk is linked to modern and costly technologies. However, the adoption of simple and low-cost measures enables obtaining better quality product (MAIA et al., 2013).

To improve milk quality and comply with legislation, NIs recommend the qualification and training of all workers involved in the milk production chain (BRAZIL, 2018). In this context, Battaglini et al. (2013) evaluated 201 dairy farms in the central region of Paraná in order to characterize dairy production aspects and the dissemination of good milking practices. The authors observed that the mean SPC of milk was $60 \%$ ( $P$ $<0.05)$ lower after training. In addition, significant difference in SPC $(P<0.05)$ values was observed for producers who received training when compared with those who did not.

Ribeiro Júnior et al. (2014) associated the effect of good milking practices, including the implementation of FSM, on the sanitary hygienic aspects of 92 dairy farms in the midnorthern region of the state of Paraná, Brazil. Among dairy farms evaluated, $53.3 \%(\mathrm{n}=49)$ implemented all or some good practices, with significant reduction in SPC $(P<0.05)$ from $3.8 \times 10^{6}$ to $1.8 \times 10^{5} \mathrm{CFU} / \mathrm{mL}$, but without significant effects on SCC. After the adoption of good milking practices, only $6.1 \%$ of the 49 dairy farms continued to present bacterial counts greater than $7.5 \times 10^{5} \mathrm{CFU} / \mathrm{mL}$, as stipulated by the current legislation at the time. The authors attributed the resistance to adherence to good practices to the lack of incentives by the industry regarding the production of quality milk, as reported by farmers during the performance of this study.
The implementation of quality payment programs by dairy companies has positive impact on the production of quality milk. Beloti et al. (2012) analyzed the effect of good milking practices, including the implementation of FSM, on the hygienic-sanitary aspects of 49 dairy farms in the region of Ivaiporã, PR, Brazil, with average SPC value of $5.9 \times 10^{5} \mathrm{CFU} / \mathrm{mL}$. After training and implementing good milking practices, the authors observed a statistically significant $(P<0.05)$ reduction in SPC, with average value of $708,630 \mathrm{CFU} / \mathrm{mL}$ over the four months of project execution. In addition, the SCC values decreased significantly from $700 \times 10^{3}$ cells $/ \mathrm{mL}$ to $417 \times 10^{3}$ cells $/ \mathrm{mL}$.

Another factor that reinforces the importance of implementing FSM is that the greater the milk volume collected in the test, the fewer somatic cells will be present in milk from the cooling tank. This was evident when aspects of milk from FSM collected during morning and afternoon milkings were compared (Table 4). In the morning milking, although milk volume was higher, the somatic cell score was significantly lower. On the other hand, in the afternoon milking SCC was higher. Generally, the highest milk production occurs in the morning milking due to longer milking intervals, and lower SCC values are observed due to the dilution effect (BONDAN et al., 2019). Furthermore, the milking interval influences milk quality and production aspects. Fernando and Spahr (1983) demonstrated that the lower SCC values is related to milking intervals between eight and ten hours. Intervals lesser than six hours increased SCC for both healthy and unhealthy quarters (NIELSEN et al., 2005). This SCC rise could be connected to insufficient time to mammary gland recovery after milking (NEIJENHUIS; KLUNGEL; HOGEVEEN, 2001). The choice of milking intervals by farmers should consider improvement and optimization of production, milk quality, labor' cost and management and unforeseen circumstances (CHARTON et al., 2016).

In addition, there may be an environmental effect on milk production, in which animals under thermal stress, especially during the day, reduce dry matter intake and consequently milk production, a common condition observed in the summer seasons of tropical climates (KOÇ, 2015).

\section{CONCLUSION}

The application of the FSM in the milking management did not show influences on the sanitary and hygienic aspects of milk from the cooling tank in the present study. Milk from FSM has statistically different hygienic-sanitary characteristics between morning and afternoon milkings. However, FSM is a good practice that should be implemented as a daily routine, as its performance in dairy farms with indexes above maximum parameters established by legislation would significantly contribute to improve milk quality of the cooling tank. The elimination of the first milk streams is a low-cost and simple practice, that could either aid farmers in the diagnosis of bovine mastitis and allow the elimination of the milk fraction possibly contaminated by external agents. 


\section{REFERENCES}

ALI, A. K. A.; SHOOK, G. E. An optimum transformation for somatic cell concentration in milk. Journal of Dairy Science, v. 63, p. 487490, 1980.

BATTAGLINI, A. P. P. et al. Difusão de boas práticas e caracterização de propriedades leiteiras. Archivos de Zootecnia, v. 62, p. 151-154, 2013.

BAVA, L. et al. Effect of cleaning procedure and hygienic condition of milking equipment on bacterial count of bulk tank milk. The Journal of Dairy Eesearch, v. 78, n. 2, p. 2ll-219, 2011.

BELOTI, V. et al. Impacto da implantação de boas práticas de higiene na ordenha sobre a qualidade microbiológica e físico-química do leite cru refrigerado. Revista do Instituto de Laticínios Cândido Tostes, v. 67, п. 388, p. 05-10, 2012.

BONDAN, C. et al. Variation of cow's milk composition across different daily milking sessions and feasibility of using a composite sampling. Ciência Rural (online), https:/doi.org/10.1590/01038478cr20181004, v. 49, п. 6, 2019.

BRASIL. Ministério da Agricultura, Pecuária e Abastecimento. Instrução Normativa n. 76, de 26 de novembro de 2018. Aprova os regulamentos técnicos de identidade e as características de qualidade que devem apresentar o leite cru refrigerado, o leite pasteurizado e o leite pasteurizado tipo A. Diário Oficial da União, Brasília, Seção l, 30 nov. 2018.

CASSOLI, L. D.; MACHADO, P. F. Mapa da qualidade do leite: Contagem bacteriana total (CBT). Piracicaba, SP: Clínica do leite. /ESALQ/USP, v.2, 36p, $2016 a$.

CASSOLI, L. D. et al. Mapa da qualidade do leite: contagem de células somáticas (CCS). Piracicaba, SP: Clínica do Leite/ESALQ/ USP, 36p, 2016b.

CHARTON, C. et al. Individual responses of dairy cows to a 24-hour milking interval. Journal of Dairy Science, v. 99, n. 4, p. 3103$3112,2016$.

DIAS, J.A.; ANTES, F. G. Qualidade físico-química, higiênico-sanitária e composicional do leite cru: indicadores e aplicações práticas da Instrução Normativa 62. Embrapa Rondônia, 19p., 2014.

FERNANDO, R. S.; SPAHR, S. L. Effects of milking interval on selected milk constituents from normal and infected quarters. Journal of Dairy Science, v. 66, n. 5, p. 1155-1161, 1983.

$\mathrm{KOC \zeta ,} \mathrm{A.} \mathrm{Effects} \mathrm{of} \mathrm{somatic} \mathrm{cell} \mathrm{count} \mathrm{and} \mathrm{various} \mathrm{environmental}$ factors on milk yield and foremilk constituents of red-holstein cows. Tarim Bilimleri Dergisi - Journal of Agricultural Sciences, v. 21, p. 439-447, 2015.

MAIA, G. B. DAS. et al. Produção leiteira no Brasil. BNDES Setorial, v. 37, p. 371-398, 2013.

MELO SOARES, E. S. de M.S. et al. Application of good milking practices: economic impacts and bovine raw milk quality. Multitemas, v. 24, n. 56, p. 41-57, 2019.
MENEZES, M. F. et al. Microbiota e conservação do leite. Revista Eletrônica em Gestão, Educação e Tecnologia Ambiental, v. 18, p. 76-89, 2014.

NEIJENHUIS, F.; KLUNGEL, G. H.; HOGEVEEN, H. Recovery of cow teats after milking as determined by ultrasonographic scanning. Journal of Dairy Science, v. 84, n. 12, p. 2599-2606, 2001.

NIELSEN, N. I. et al. Quarter health, milking interval, and sampling time during milking affect the concentration of milk constituents. Journal of Dairy Science, v. 88, n. 9, p. 3186-3200, 2005.

REYES, J. et al. Influence of milking method, disinfection and herd management practices on bulk tank milk somatic cell counts in tropical dairy herds in Colombia. Veterinary Journal, v. 220, p. 34-39, 2017.

RIBEIRO JÚNIOR, J. C. et al. Influência de boas práticas de higiene de ordenha na qualidade microbiológica do leite cru refrigerado. Revista do Instituto de Laticínios Cândido Tostes, v. 69, n. 6, p. 395-404, 2014.

RUEGG, P. L. Practical food safety interventions for dairy production. Journal of Dairy Science, v. 86, E. Suppl., p. El-E9, 2003.

SANTOS, M. V.; FONSECA, L.F.L. Controle de mastite e qualidade do leite - Desafios e soluções. Pirassununga-SP: Edição dos Autores, 30lp, 2019.

SHOOK, G. E. et al. Relationship between intramammary infection prevalence and somatic cell score in commercial dairy herds. Journal of Dairy Science, v. 100, p. 9691-9701, 2017.

STERRETT, A. E.; BEWLEY, J. M. Characterization of management practices used on Kentucky dairy farms with low somatic cell counts. Professional Animal Scientist, v. 29, n. 4, 359-366, 2013.

UJITA, A. et al. Effect of positive tactile stimulation and prepartum milking routine training on behavior, cortisol and oxytocin in milking, milk composition, and milk yield in Gyr cows in early lactation. Applied Animal Behaviour Science, v. 234, 2021.

WAGNER, A. M.; RUEGG, P. L. The effect of manual forestripping on milking performance of Holstein dairy cows. Journal of Dairy Science, v. 85, p.804-809, 2002.

WATTERS, R. D. et al. The effect of manual and mechanical stimulation on oxytocin release and milking characteristics in Holstein cows milked 3 times daily. Journal of Dairy Science, $v$. 98, п. 3, p. 1721-1729, 2015.

WERNCKE, D. et al. Qualidade do leite e perfil das propriedades leiteiras no sul de Santa Catarina: Abordagem multivariada. Arquivo Brasileiro de Medicina Veterinaria e Zootecnia, v. 68, n. 2, p. 506-516, 2016.

YAMAZI, A. K. et al. Práticas de Produção aplicadas no controle de contaminação microbiana na produção de leite cru. Bioscience Journal, v. 26, n. 4, p. 610-618, 2010. 